\title{
EVALUATION OF MICROBIAL FLORA IN PATIENTS WITH GINGIVAL ENLARGEMENT DURING THE TREATMENT AND SURFACE CHEMISTRY OF FIXED ORTHODONTIC APPLIANCE ARCHWIRE
}

\author{
OVREDNOTENJE MIKROBNE FLORE PRI PACIENTIH S \\ POVEČANJEM DLESNI MED OBRAVNAVO IN ANALIZA \\ POVRŠINE ŽIČNEGA LOKA NESNEMNEGA ORTODONTSKEGA \\ APARATA
}

\author{
Rok Ovsenik $^{1 *}$ Miha Pirc ${ }^{2 *}$,Jasmina Primožič ${ }^{1}$, Rok Schara ${ }^{2}$, Janez Kovač ${ }^{3}$, \\ Monika Jenko ${ }^{4,5}$, Boris Gašpirc ${ }^{2}$ \\ ${ }^{1}$ Department of Orthodontics and Dentofacial Orthopaedics, Faculty of Medicine, University of Ljubljana, \\ Hrvatski trg 6, 1000 Ljubljana, Slovenia \\ ${ }^{2}$ Department of Oral Medicine and Periodontology, Faculty of Medicine, University of Ljubljana, Hrvatski trg 6, 1000 Ljubljana, Slovenia \\ ${ }^{3}$ Jožef Stefan Institute, Jamova 39, 1000 Ljubljana, Slovenia \\ ${ }^{4}$ Institute of Metals and Technology, Lepi pot 11, 1000 Ljubljana Slovenia \\ ${ }^{5}$ MD-RI Institute for Materials Research in Medicine, Bohoričeva 5, 1000 Ljubljana Slovenia
}

Prejem rokopisa - received: 2020-07-15; sprejem za objavo-accepted for publication: 2020-08-13

\section{doi:10.17222/mit.2020.137}

\begin{abstract}
Gingival enlargement is a common complication of treatment with a fixed orthodontic appliance, biocompatible stainless-steel archwires AISI 304L (SS). Due to the retention areas, dental plaque accumulation is increased, which results in anaerobic conditions, favourable for periodontopathogenic bacteria. Therefore, it is reasonable to assume that periodontopathogenic bacteria can be found in patients with fixed orthodontic appliances. Organic deposits on the surface of archwires were analyzed. Twenty-one patients with fixed orthodontic appliances and gingival enlargement in the upper dental arch were included in the study. For a determination of the periodontopathogenic bacteria Aggregatibacter actinomycetemcomitans, Porphyromonas gingivalis, Prevotella intermedia, Tannerella forsythia and Treponema denticola the molecular microbiological method GenoType Test System was used. For the surface analysis of new and in-vivo exposed SS archwires X-ray Photoelectron Spectroscopy was used. The average probing depth at the baseline was $3.76 \pm 0.85 \mathrm{~mm}$. Three types of periodontopathogenic bacteria, namely $A$ actinomycetemcomitans, $T$, forsythia and $T$. denticola, were found to be present. The thickeness of the thin oxide film on new archwires was $8 \mathrm{~nm}$, while organic deposits on the in-vivo exposed archwires was estimated to 60-80 nm. Anaerobic periodontopathogenic bacteria can be found in patients with fixed orthodontic appliances. Therefore, special care is recommended during this kind of treatment.
\end{abstract}

Keywords: biocompatible stainless steel, AISI 304L, archwires, periodontopathogenic bacteria, gingival enlargement, fixed orthodontic appliance, X-ray photoelectron spectroscopy (XPS)

Povečanje dlesni je pogost zaplet zdravljenja z nesnemnim ortodontskim aparatom. Povečanje je posledica velikega števila zastojnih mest in posledično kopičenja zobnih oblog, kar privede do vzpostavitve anaerobnih pogojev, primernih za naselitev parodontopatogenih bakterij. Analizirali smo organske obloge na kovinskih lokih iz nerjavnega jekla (SS) AISI 3014L. V preiskavo smo vključili 21 pacientov s povečanjem dlesni v zgornjem zobnem loku, ki so imeli nameščen nesnemni ortodontski aparat; kovinski loki, ki so bili vstavljeni, pa so bili iz biokompatibilnega nerjavnega jekla, AISI 304 L (SS). Pri vseh smo preverjali prisotnost parodontopatogenih bakterij Aggregatibacter actinomycetemcomitans, Porphyromonas gingivalis, Prevotella intermedia, Tannerella forsythia in Treponema denticola z molekularno mikrobiološko metodo GenoType Test System. Z rentgensko fotoelektronsko spektroskopijo (XPS) smo določili oksidno plast na novih in organske obloge na in-vivo izpostavljenih žičnih lokov. V preiskavi smo ugotovili prisotnost treh (3) vrst parodontopatogenih bakterij, in sicer: $A$. actinomycetemcomitans, $T$. forsythia in $T$. denticola. Debelina oksidne plasti na novih lokih je bila okrog $8 \mathrm{~nm}$, debelina organskih oblog na površini in vivo izpostavljenih lokov je bila ocenjena na 60-80 nm. Pri pacientih z nesnemnim ortodontskim aparatom je potrebna posebna pozornost, saj takšno okolje spodbuja rast parodontopatogenih bakterij.

Ključne besede: parodontopatogene bakterije, povečanje dlesni, nesnemni ortodontski aparat, biokompatibilni SS-loki, XPS

\section{INTRODUCTION}

Gingival enlargement is one of the possible complications during orthodontic treatment with fixed orthodontic appliances, with biocompatible archwires of stainless steal, AISI 304L (SS). It usually occurs 1-2

*Corresponding author's e-mail:

rok.ovsenik@mf.uni-lj.si (Rok Ovsenik) months after the insertion of the appliance and is present in $10 \%$ of patients. ${ }^{1}$ Gingival enlargement forms due to inflammatory factors, pharmacological substances or in connection with neoplastic formations. However, the most common cause for gingival enlargement is chronic inflammation, which is caused by the deposition of dental plaque..$^{2-4}$ 
Different mechanical factors effect friction forces during orthodontic treatment and tooth movement, in particular the brackets, SS (stainless steel) and NiTi (nickel-titanium) archwires. ${ }^{5}$ Fixed orthodontic appliances allow the colonization of important periodontopathogenic bacteria. ${ }^{6,7}$ Etiological factors for the occurrence of gingival enlargement in patients with fixed orthodontic appliances are: i) mechanical irritation of the appliance, ii) chemical irritation of substances with which brackets are attached to the teeth and iii) food jamming as perfect oral hygiene is much harder to maintain. ${ }^{8}$

The composition of oral flora depends on different factors, but mostly on eating habits and oral hygiene. According to the literature, there are more than $80 \%$ of facultative anaerobic microbes, which can grow either in the presence or absence of oxygen, streptococci and bacilli (such as Actinomyces) and $15 \%$ of anaerobic bacilli (such as Fusobacterium and Bacteroides), in a healthy gingiva with periodontal pockets up to $2 \mathrm{~mm}$. With the presence of inflammation, the share of aerobic bacteria decreases, while the share of anaerobic bacteria increases. ${ }^{9,10}$

The colonization of bacteria on hard surfaces of the teeth and their metabolism is the most common cause for caries, gingival inflammation, periodontal disease, periimplantitis, stomatitis and candidiasis. ${ }^{11-13}$ In order for gingival inflammation to occur, three criteria must be fulfilled:

1) the presence of a significant number and species of bacteria in the oral flora,

2) the presence of retention places, which enable growth of anaerobic bacteria and

3) a weakened immune system of the host. ${ }^{9}$ The number of retention places greatly increases in patients with fixed orthodontic appliances and therefore the inflammatory response of the organism is more frequent. ${ }^{7,14,15}$

Most bacteria have the ability to attach themselves on hard surfaces of the teeth, which enables the accumulation of dental plaque. With the growing accumulation of dental plaque the need for nutrients traveling by diffusion increases. The inner structure of the dental plaque becomes a perfect environment for the colonization of anaerobic bacteria, while most nutrients for bacteria in plaque come from saliva and ingested food. However, this is not the case when it comes to bacteria forming subgingival plaque. Since access for nutrients coming from saliva and ingested food is limited, they get nutrients from deeper periodontal pockets, mostly from blood and periodontal tissue. ${ }^{9}$ There are $10^{8}$ bacteria per $\mathrm{mm}^{3}$ of dental plaque, producing acids, endotoxins and antigens, which results in irritation of the periodontal tissue, its inflammation and with prolonged impact even in periodontal tissue damage. ${ }^{10}$

Therefore, the aim of this study was to determine the change in probing depth and the presence of period- ontopathogenic bacteria in patients with gingival enlargement during orthodontic treatment with fixed orthodontic appliances and surface chemistry of new and in-vivo-exposed biocompatible SS archwires.

\section{MATERIALS AND METHODS}

This prospective study was performed at the Department of Orthodontics and Dentofacial Orthopaedics at the University Medical Centre Ljubljana and Orthos over a period of 3 months. A signed, written consent was acquired before a patient was included to the study. This study was approved by the local ethics committee (KME 79/08/13).

Patients treated at the Department of Orthodontics and Dentofacial Orthopaedics, University Medical Centre Ljubljana and Orthos, were included in the study. All the patients were wearing fixed orthodontic appliances for at least 2 years and were therefore on rectangular biocompatible stainless steel AISI 304L (SS) archwires. They had gingival enlargement in the upper dental arch bilaterally (Figure 1). Patients with allergies, craniofacial syndromes and systemically unhealthy patients were excluded from the study.

Medical history and clinical examination were carried out at the beginning of the study. Periodontal pocket depth was measured at 6 points and two microbiological
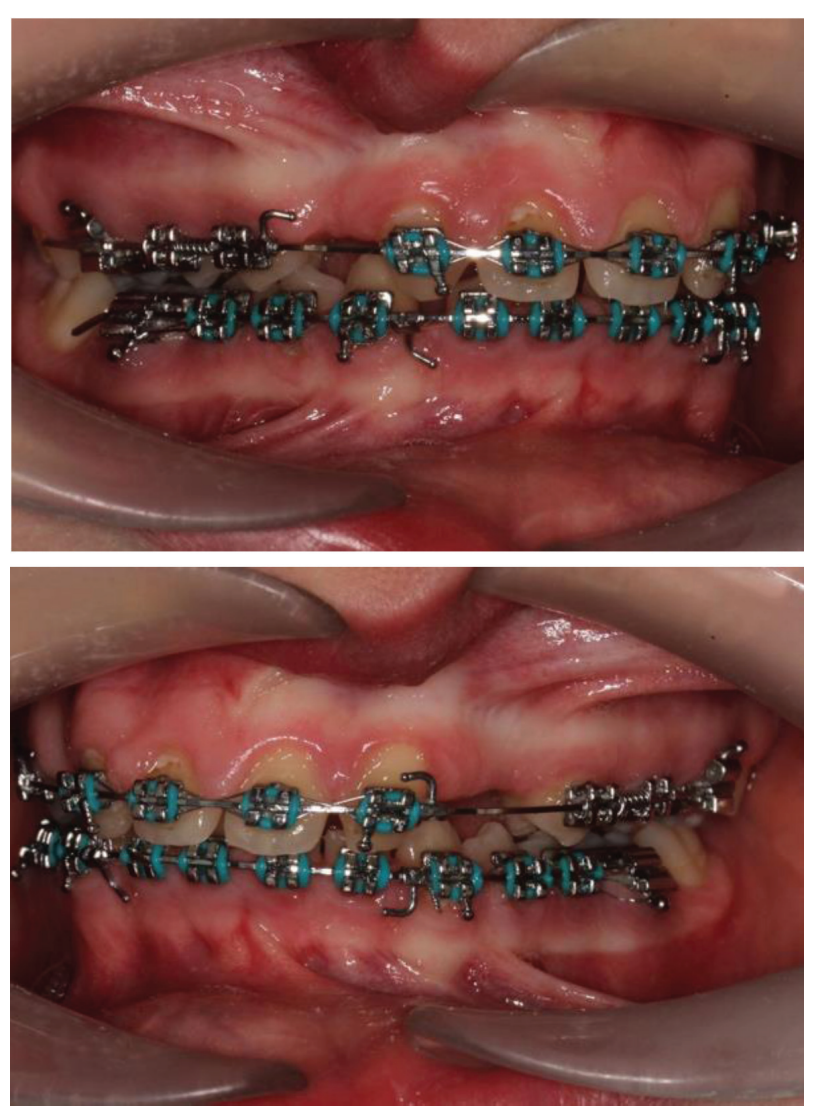

Figure 1: Intraoral photograph of a patient on SS archwires and gingival enlargement in the upper dental arch bilaterally 
samples from each patient were obtained. The microbiological sample was taken from the deepest periodontal pocket on the left and right sides of the upper dental arch.

Before microbiological samples were taken, supragingival plaque was removed with ultrasound. A sterile paper point was inserted into the periodontal pocket for $10 \mathrm{~s}$, using sterile tweezers without the interference of saliva, in order to guarantee only subgingival bacteria in the sample (Figures $\mathbf{2 a}$ and $\mathbf{2 b}$ ). The paper point was removed after 10 seconds and was then inserted into the appropriate sterile test tube. The samples were analysed by the molecular microbiological method GenoType Test System usingmicro-IDent ${ }^{\circledR}$ (Hain Lifescience $\mathrm{GmbH}$, Nehren, Germany).

For the evaluation of microbial flora in the periodontal pocket the micro-IDent ${ }^{\circledR}$ (Hain Lifescience $\mathrm{GmbH}$, Nehren, Germany) was used. It makes it possible to determine the presence and concentration of the five most common and most aggressive species of periodontopathogenic bacteria, namely: Aggregatibacteractinomycetemcomitans, Porphyromonasgingivalis, Prevotella intermedia, Tannerella forsythia and Treponemadenticola, which are all Gram-negative bacteria.

The samples were analysed by the molecular microbiological method GenoType Test System (Figures 3a and 3b), where bacterial DNA was isolated using QiaAmp DNA Mini Kit (QIAGEN, Hilden, Germany) and the addition of a buffer. The isolated DNA was kept at $-20{ }^{\circ} \mathrm{C}$ until it was mixed together with two pre-prepared reagents and multiplied by the PCR method. PCR (polymerase chain reaction) consists of three phases. In phase I the double-screw molecular sample of DNA is separated into two single-screw DNA molecules at

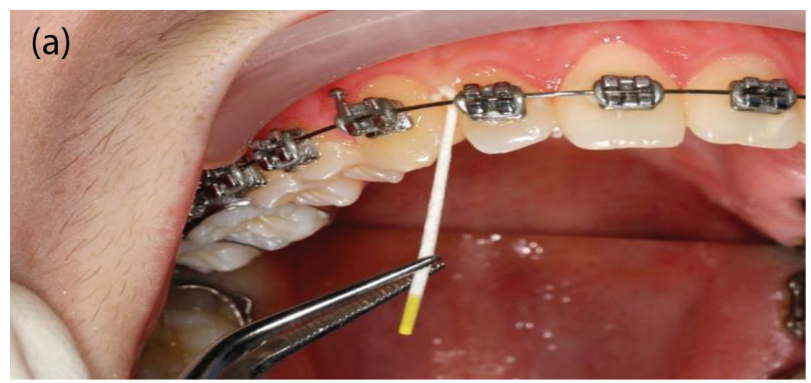

(b)

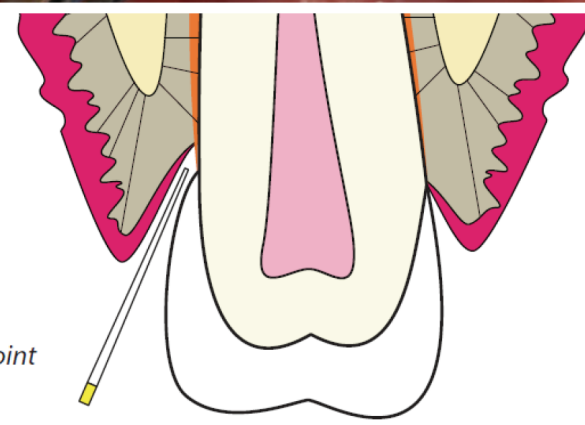

Figure 2: a) Procedure for obtaining microbiological sample and b) schematic view of inserting paper points into periodontal pockets

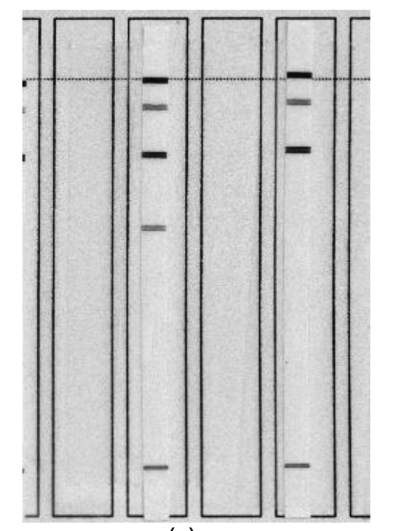

(a)

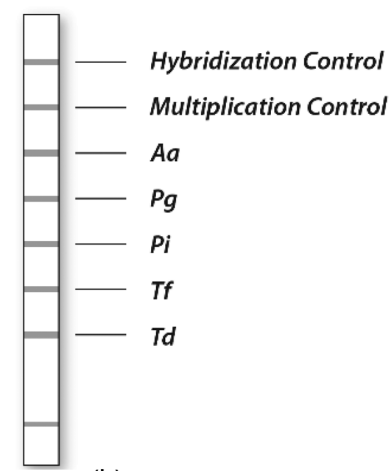

(b)
Figure 3: a) The result of bacterial proof using molecular microbiological method and b) schematic view of the bacterial proof result

90-96 ${ }^{\circ} \mathrm{C}$. Phase II is where nucleotides start to bond to the single-screw DNA molecule at $40-75{ }^{\circ} \mathrm{C}$, which we call hybridization. Phase III is where, at $65-75{ }^{\circ} \mathrm{C}$ and by the help of polymerase, the synthesis of DNA is finished. Each temperature cycle that follows doubles the amount of the target DNA part. PCR usually consists of 25-40 consecutive repetitions of the temperature cycle resulting in exponential accumulation of typical target parts of the DNA.

\subsection{Statistical analysis}

The SPSS program (The Statistical Package for Social Science SPSS Inc., Chicago, Illinois, USA) was used for statistical data analysis. In case of a normal distribution, parametric statistical tests were used, otherwise we used nonparametric statistical tests. The McNemar test was used to determine differences in the proportion of periodontopathogenic bacteria. Five patients were randomly selected to determine the inter- and intra-examiner variability, which were then assessed using ICC (Interclass Correlation Coefficient) and interpreted after Landis and Koch (1977). ${ }^{16}$ To determine the statistical significance, the standard value for the confidence interval of at least $95 \%(p<0.05)$ was used.

\subsection{XPS surface analysis}

The XPS measurements of the thin oxide film on new and organic deposit - dental plaque on in-vivo exposed (SS) archwires were performed using non-monochromatic $\mathrm{Al}-K_{\alpha}$ radiation $(1486.6 \mathrm{eV})$ with an anode voltage of $12.5 \mathrm{kV}$ and an emission current of $16 \mathrm{~mA}(200 \mathrm{~W})$. For the XPS depth profiling, a 3-keV Ar-ion beam scanned over a $4 \mathrm{~mm} \times 5 \mathrm{~mm}$ area was used, and this corresponded to a $0.1 \mathrm{~nm} / \mathrm{min}$ sputtering rate.

XPS measurements were made at an emission angle of $0^{\circ}$. The analysed area is about $1 \mathrm{~mm} \times 2 \mathrm{~mm}$, so the results represent a laterally averaged chemical composition over this area. Survey scans covering the binding-energy range $0-1200 \mathrm{eV}$ were taken for each sample 
with a constant analyser pass energy of $50 \mathrm{eV}$. The high-resolution XPS measurements were taken at a pass energy of $25 \mathrm{eV}$ to allow for a determination of the oxidation state of the elements.

\section{RESULTS}

\subsection{Evaluation of microbial flora in patients with gingival enlargement and statistical analysis}

The average probing depth among all subjects in the study was $3.76 \pm 0.85 \mathrm{~mm}$.

The proportion of individual bacteria in the subjects is presented in Table 2. Three species of periodontopathologic bacteria were detected, namely A. actinomycetemcomitans, T. forsythia and T. denticola (Table 1).

Table 1: Number of subjects with the presence of individual bacteria (\%); Aggregatibacteractinomycetemcomitans (A.a.), Porphyromonas gingivalis (P.g.), Prevotella intermedia (P.i.), Tannerella forsythia (T.f.) and Treponema denticola (T.d.) in periodontal pockets on both sides of the arch

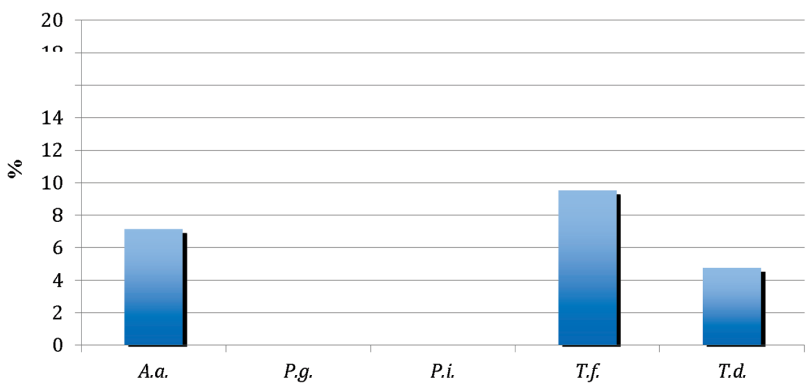

\subsection{XPS analysis results of new and in-vivo exposed SS archwires}

Figure 4 shows an XPS survey spectrum from the surface of a new SS sample. The elements $\mathrm{C}, \mathrm{O}, \mathrm{Fe}$ and $\mathrm{Si}$ are present on the surface. The $\mathrm{Fe} 2 \mathrm{p}_{3 / 2}$ spectrum has a maximum at $711 \mathrm{eV}$, which means that $\mathrm{Fe}$ is present as

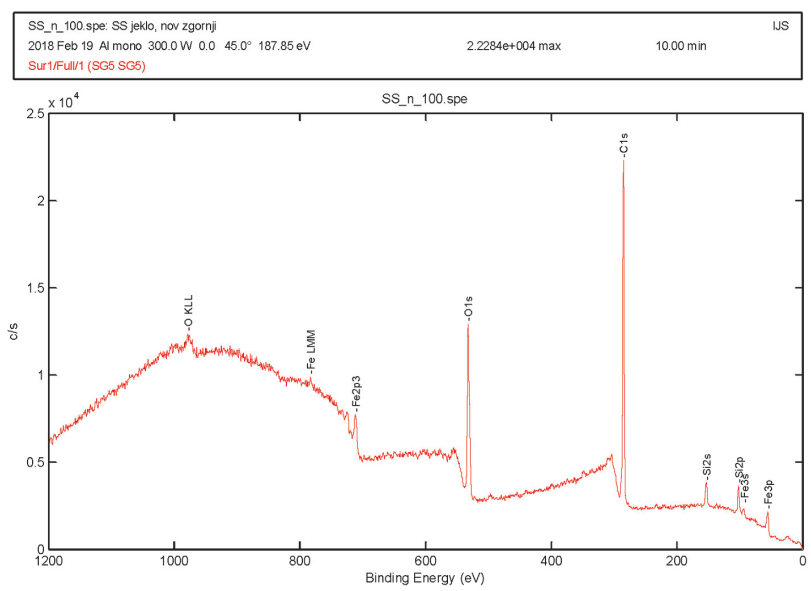

Figure 4: XPS spectrum from the surface of a new SS sample. Elements $\mathrm{C}, \mathrm{O}, \mathrm{Fe}$ and $\mathrm{Si}$ are present on the surface

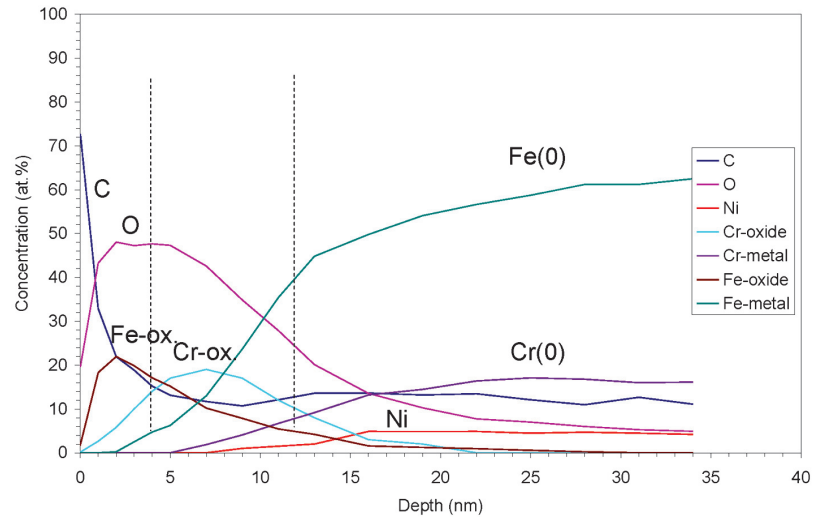

Figure 5: XPS depth profile of a new SS sample

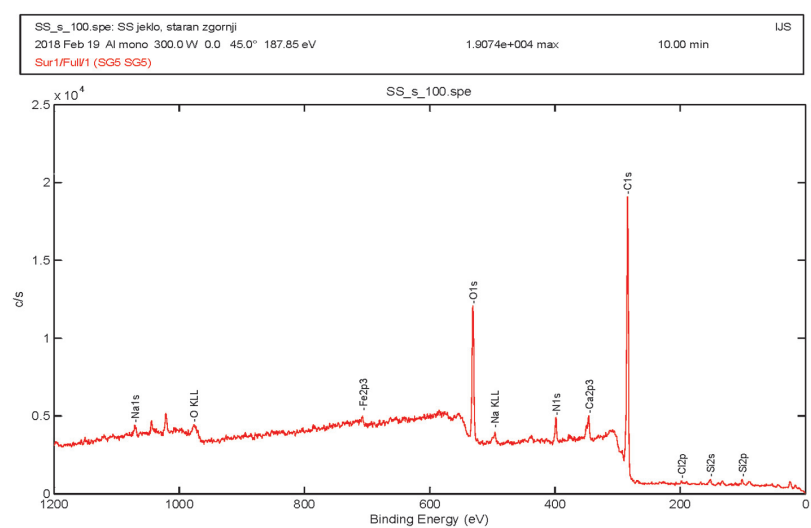

Figure 6: XPS spectrum from the surface of in-vivo exposed SS sample. Elements $\mathrm{C}, \mathrm{O}, \mathrm{Fe}, \mathrm{Si}, \mathrm{Na}, \mathrm{Cl}, \mathrm{Ca}$ are present on the surface

Fe-oxide on the surface. Figure 5 shows an XPS depth profile of a new SS sample. We decomposed the Fe $2 p$ and $\mathrm{Cr} 2 \mathrm{p}$ spectra into metallic peaks $(\mathrm{Fe}(0)$ at $707.0 \mathrm{eV}$ and $\mathrm{Cr}(0)$ at $574.4 \mathrm{eV}$ ) and oxide peaks (Fe-oxide at $711 \mathrm{eV}$ and $\mathrm{Cr}$-oxide at $576.8 \mathrm{eV}$ ). We found that the surface is covered with double oxide layer. The top-most layer consists mainly of $\mathrm{Fe}$-oxide and it is about $4 \mathrm{~nm}$ thick. Beneath this layer is a Cr-oxide/Fe-oxide mixed layer of thickness about $8 \mathrm{~nm}$. This mixed Fe-Cr-oxide layer was grown on the SS matrix consisting of

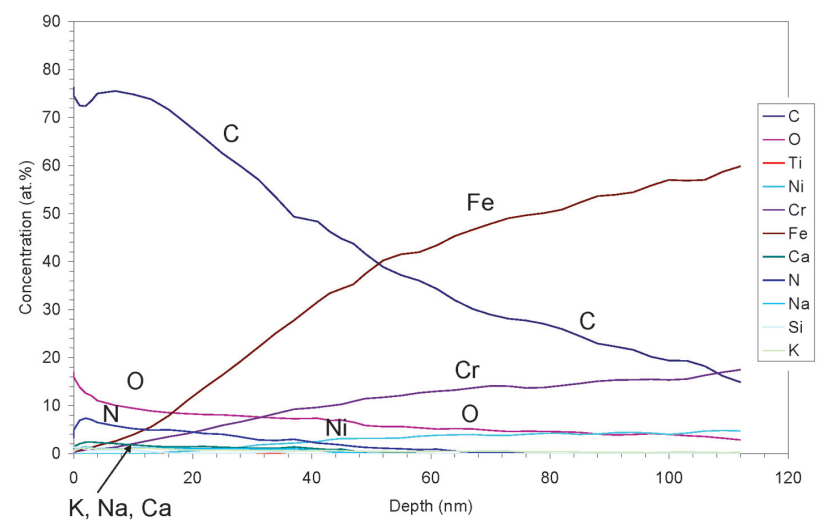

Figure 7: XPS depth profile of an exposed SS sample 
Fe-Cr-Ni. The surface of the exposed sample is covered with a very thin C-rich layer (1-2 $\mathrm{nm})$ of contamination, where $\mathrm{Si}$ is also detected. Figure 6 shows an XPS spectrum from the surface of exposed SS sample. Elements $\mathrm{C}, \mathrm{O}, \mathrm{Fe}, \mathrm{Si}, \mathrm{Na}, \mathrm{Cl}$ and $\mathrm{Ca}$ are present on the surface. Figure 7 shows an XPS depth profile of elements of the subsurface region on the exposed SS sample. The SS sample is covered with 60-80-nm-thick layer rich in carbon, wherein also $\mathrm{O}, \mathrm{N}, \mathrm{Ca}, \mathrm{K}, \mathrm{Na}$ and $\mathrm{Si}$ are present. This layer was formed during exposure of the SS sample.

\section{DISCUSSION}

The study shows that in a certain percentage of subjects during treatment with fixed orthodontic appliances, periodontopathogenic bacteria can be found. The highest percentage had T. forsythia (9.52\%), following with A. actinomycetemcomitansin $7.14 \%$ of subjects and T. denticolain $4.76 \%$ of subjects.

A. actinomycetemcomitans, a facultative anaerobic Gram-negative bacteria, is one of the first organisms connected with the early stage of the periodontal disease. ${ }^{17,18}$ It was found that there is a connection between an increased pocket depth and quantity of A. actinomycetemcomitans subgingivally. ${ }^{19}$ The larger the quantity of $A$. actinomycetemcomitans subgingivally, the lower the success of a classic periodontal treatment and the lesser pocket-depth reduction. A. actinomycetemcomitans is the only anaerobic species, which is present already at an early age, between 5-7 years, and persists in the oral flora even later. ${ }^{20,21}$ A. actinomycetemcomitans was present in $7.14 \%$ of the subjects. Paolantonio et. $\mathrm{al}^{22}$ reported that the increase in quantity of A. actinomycetemcomitans occurs after the bonding of fixed orthodontic appliances, since the increased plaque accumulation positively induces the colonization of A. actinomycetemcomitans. ${ }^{22}$ Changes in the oral flora of subgingival plaque in general after the bonding of fixed orthodontic appliances is well reported in the literature. ${ }^{23-25}$ However, the change in microbial flora soon after the bonding of fixed orthodontic appliances only persists for a short period of time, since the immune system recovers again after three months and a balanced state is established. ${ }^{1}$

Orthodontic treatment with fixed orthodontic appliances causes increased plaque accumulation and decreases the ability for a mechanical removal of plaque, since the number of retention surfaces increases severely. ${ }^{26}$ All non-linear parts of the appliance greatly decrease the ability of mastication and salivary flow to remove bacteria from these surfaces, this is why a larger accumulation of plaque on the surfaces is more probable, which can lead to a severe periodontal tissue inflammation. ${ }^{27}$ The presence of periodontal tissue inflammation additionally increases plaque accumulation. ${ }^{14,28,29}$ Stainless steel rectangular archwires, when exposed to the intraoral environment, showed a significant increase in the amount of debris accumulation, ${ }^{30}$ while a significant correlation between the amount of debris and friction was also observed. ${ }^{31}$ On the other hand, some investigators have concluded that in order to lower the presence of bacteria it is beneficial to carefully clean brackets and archwires at each visit as the amount of debris accumulation increases significantly with exposure. ${ }^{5}$

In the present study $P$. gingivalis and $P$. intermedia are not the present microbial flora of subgingival plaque in patients with gingival enlargement during treatment with fixed orthodontic appliances. The results coincide with the study of W. E. Moore et al., ${ }^{32}$ who found high concentrations of $P$. gingivalis in the supragingival, but not in the subgingival plaque. The presence of $P$. gingivalis is usually associated with the occurrence of advanced periodontitis in adult patients and with early stages of a localised periodontal disease, although its presence is not as pathogenic as that of A. actinomycetemcomitans. ${ }^{21}$ Assuming that all of our subjects have taken good care of their oral hygiene and that before every microbiological sample was taken and the supragingival plaque removed, the absence of P.gingivalisis was expected. According to the literature A. actinomycetemcomitans and $P$. gingivalis are only rarely present at the same time..$^{32-34}$

$P$. gingivalis was not present in patients with gingival enlargement, while its share in the Slovenian patients with chronic periodontitis was equally high $(93.3 \%) .{ }^{35}$

The quantitative alteration of the oral microbiota is related to an increase in clinical parameters, plaque index and bleeding on probing, which are risk indicators for periodontal pathologies. ${ }^{36}$ Together with the quantitative change, there is also a qualitative variation; indeed, there is an increase in more aggressive gram-positive and gram-negative bacteria, such as: $S$. mutans and Lactobacillus spp. (gram-positive) and P. gingivalis, T. forsythia, and T. denticola (gram-negative). These bacteria are closely associated with, respectively, enamel and dentin pathologies and with periodontal disease. ${ }^{37}$ Oral microbiota alterations detected in orthodontic patients appear to be consistent with the alterations occurring in patients with poor oral hygiene presenting gingivitis and/or periodontal diseases. ${ }^{23,38,39}$ However, the susceptibility of each subject as well as other factors that may alter the biofilm balance, can play a key role in determining the entity of periodontal consequences.

The results of in-vivo exposed SS archwire XPS surface analysis confirmed elements $\mathrm{C}, \mathrm{O}, \mathrm{Fe}, \mathrm{Si}, \mathrm{Na}, \mathrm{Cl}$, $\mathrm{Ca}$ on the surface. An XPS depth profile of the elements of the subsurface region on the exposed SS sample showed that the SS archwire sample is covered with a 60-80 nm thick layer rich in carbon, wherein also O, N, $\mathrm{Ca}, \mathrm{K}, \mathrm{Na}$ and $\mathrm{Si}$ are present. ${ }^{41}$ This layer was formed during in-vivo exposure of the SS sample.

The most important result is the determination of the deposit thickness of an in-vivo exposed SS archwire, where a $60-80$-nm-thick organic film is formed contain- 
ing $\mathrm{O}, \mathrm{N}, \mathrm{Fe} \mathrm{Si}, \mathrm{Na}, \mathrm{Cl}$ and $\mathrm{Ca}$. This layer growth during in-vivo exposure is dental plaque, since it is of organic origin. FTIR results of our previous studies showed that the presence of the minerals apatite $\mathrm{Ca}_{5}\left(\mathrm{PO}_{4}\right)_{3}(\mathrm{~F}, \mathrm{Cl}, \mathrm{OH})$, calcite $\left(\mathrm{CaCO}_{3}\right)$, halite $(\mathrm{NaCl})$ and sylvite $(\mathrm{KCl})^{42}$

\section{CONCLUSIONS}

This study proved the presence of periodontopathogenic bacteria in the periodontal pockets of subjects with gingival enlargement during a treatment with fixed orthodontic appliances. However, the proportion was low in comparison to the patients with chronic periodontitis. Considering the results, it is reasonable to conclude that even though the share of periodontopathogenic bacteria is low in patients with gingival enlargement during treatment with fixed orthodontic appliances, additional hygiene measures are mandatory. Special precautions have to be made in order to prevent a greater increase in the quantity of periodontopathogenic bacteria, which can lead to a severe periodontal tissue inflammation and consequently periodontal attachment loss. A passive oxide film of 6-8 nm in thickness and a 60-80-nm-thick organic film containing $\mathrm{O}, \mathrm{N}, \mathrm{Fe}, \mathrm{Si}, \mathrm{Na}, \mathrm{Cl}$ and $\mathrm{Ca}$, where confirmed on in-vivo exposed SS archwires. This layer growth during in-vivo exposure is dental plaque, since it is of organic origin. Therefore, it would be appropriate for patients undergoing dedicated hygiene protocols to keep the oral bacterial charge under control and then to reduce the risk of the carious process and periodontal disease.

\section{Acknowledgment}

We would like to thank dr Boštjan Lavriša, Nina Žagar, Petra Vidmar Nikolič and Jura Štok for their kind collaboration during the research performed at the Department of Orthodontics and Dentofacial Orthopaedics, Faculty of Medicine, Univeristy of Ljubljana, and to Orthos specialists dr. Tomaž Košorok, dr. Maša Farkaš and dr. Martina Zore Albreht for their kind collaboration.

\section{REFERENCES}

${ }^{1}$ S. Zachrisson, B. U. Zachrisson, Gingival condition associated with orthodontic treatment, Angle Orthod, 42 (1972), 26-34, doi:10.1043/ 0003-3219(1972)042<0026:GCAWOT>2.0.CO;2

${ }^{2}$ J. Miranda, L. Brunet, P. Roset, M. Farre, C. Mendieta, Reliability of two measurement indices for gingival enlargement, J Periodontal Res, 47 (2012), 776-82, doi:10.1111/j.1600-0765.2012.01495.x

${ }^{3}$ L. Brunet, J. Miranda, M. Farre, L. Berini, C. Mendieta, Gingival enlargement induced by drugs, Drug Saf, 15 1996/09/01,(1996), 219-31, doi:10.2165/00002018-199615030-00007

${ }^{4}$ J. Lindhe, E. Westfelt, S. Nyman, S. S. Socransky, A. D. Haffajee, Long-term effect of surgical/non-surgical treatment of periodontal disease, J Clin Periodontol, 11 (1984), 448-58, doi:10.1111/j.1600051x.1984.tb01344.x

${ }^{5}$ U. Mezeg, J. Primozic, Influence of long-term in vivo exposure, debris accumulation and archwire material on friction force among dif- ferent types of brackets and archwires couples, Eur J Orthod, 39 (2017), 673-679, doi:10.1093/ejo/cjx007

${ }^{6}$ E. J. Sallum, D. F. Nouer, M. I. Klein, R. B. Gonçalves, L. Machion, A. Wilson Sallum, E. A. Sallum, Clinical and microbiologic changes after removal of orthodontic appliances, Am J Orthod Dentofacial Orthop, 126 (2004), 363-6, doi:10.1016/S0889540604004342

${ }^{7}$ J. van Gastel, M. Quirynen, W. Teughels, W. Coucke, C. Carels, Longitudinal changes in microbiology and clinical periodontal variables after placement of fixed orthodontic appliances, J Periodontol, 79 (2008), 2078-86, doi:10.1902/jop.2008.080153

${ }^{8}$ J. S. Kloehn, J. S. Pfeifer, The effect of orthodontic treatment on the periodontium, Angle Orthod, 44 (1974), 127-34, doi:10.1043/00033219(1974)044<0127:TEOOTO>2.0.CO;2

${ }^{9}$ I. A. Gubina M., Medicinska bakteriologija z imunologijo in mikologijo, Ljubljana, Medicinski razgledi, 2002

${ }^{10}$ J. Lindhe, N. P. Lang, T. Karring, Clinical Periodontology and Implant Dentistry, Oxford, Blackwell Munksgaard, $5^{\text {th }}$ ed 2008

${ }^{11}$ N. E. Atack, J. R. Sandy, M. Addy, Periodontal and microbiological changes associated with the placement of orthodontic appliances. A review, J Periodontol, 67 (1996), 78-85, doi:10.1902/jop.1996. 67.2.78

${ }^{12}$ J. A. Chapman, W. E. Roberts, G. J. Eckert, K. S. Kula, C. Gonzalez-Cabezas, Risk factors for incidence and severity of white spot lesions during treatment with fixed orthodontic appliances, Am J Orthod Dentofacial Orthop, 138 (2010), 188-94, doi:10.1016/ j.ajodo.2008.10.019

${ }^{13}$ U. K. Gursoy, O. Sokucu, V. J. Uitto, A. Aydin, S. Demirer, H. Toker, O. Erdem, A. Sayal, The role of nickel accumulation and epithelial cell proliferation in orthodontic treatment-induced gingival overgrowth, Eur J Orthod, 29 (2007), 555-8, doi:10.1093/ejo/cjm074

${ }^{14}$ M. Quirynen, C. Dekeyser, D. van Steenberghe, The influence of gingival inflammation, tooth type, and timing on the rate of plaque formation, J Periodontol, 62 (1991), 219-22, doi:10.1902/jop.1991. 62.3.219

${ }^{15}$ I. D. Lindel, C. Elter, W. Heuer, T. Heidenblut, M. Stiesch, R. Schwestka-Polly, A. P. Demling, Comparative analysis of long-term biofilm formation on metal and ceramic brackets, Angle Orthod, 81 2011/05/06, (2011), 907-14, doi:10.2319/102210-616.1

${ }^{16}$ J. R. Landis, G. G. Koch, The measurement of observer agreement for categorical data, Biometrics, 33 1977/03/01 ed (1977), 159-74

${ }^{17} \mathrm{~J}$. Slots, The predominant cultivable organisms in juvenile periodontitis, Scand J Dent Res, 84 (1976), 1-10, doi:10.1111/ j.1600-0722.1976.tb00454.x

${ }^{18}$ J. J. Zambon, L. A. Christersson, J. Slots, Actinobacillus actinomycetemcomitans in human periodontal disease. Prevalence in patient groups and distribution of biotypes and serotypes within families, J Periodontol, 54 (1983), 707-11, doi:10.1902/jop.1983. 54.12.707

${ }^{19}$ L. A. Christersson, Actinobacillus actinomycetemcomitans and localized juvenile periodontitis. Clinical, microbiologic and histologic studies, Swed Dent J Suppl, 90 (1993), 1-46

${ }^{20} \mathrm{~S}$. A. Alexander, Effects of orthodontic attachments on the gingival health of permanent second molars, Am J Orthod Dentofacial Orthop, 100 (1991), 337-40, doi:10.1016/0889-5406(91)70071-4

${ }^{21}$ I. Darby, M. Curtis, Microbiology of periodontal disease in children and young adults, Periodontol 2000, 26 (2001), 33-53, doi:10.1034/j.1600-0757.2001.2260103.x

${ }^{22}$ M. Paolantonio, V. Pedrazzoli, C. di Murro, G. di Placido, C. Picciani, G. Catamo, M. De Luca, R. Piaccolomini, Clinical significance of Actinobacillus actinomycetemcomitans in young individuals during orthodontic treatment. A 3-year longitudinal study, J Clin Periodontol, 24 (1997), 610-7, doi:10.1111/j.1600-051x.1997. tb00237.x

${ }^{23}$ M. Ristic, M. Vlahovic Svabic, M. Sasic, O. Zelic, Clinical and microbiological effects of fixed orthodontic appliances on periodontal tissues in adolescents, Orthod Craniofac Res, 10 (2007), 187-95, doi:10.1111/j.1601-6343.2007.00396.x 
${ }^{24}$ C. Nonnenmacher, R. Mutters, L. F. de Jacoby, Microbiological characteristics of subgingival microbiota in adult periodontitis, localized juvenile periodontitis and rapidly progressive periodontitis subjects, Clin Microbiol Infect, 7 (2001), 213-7, doi:10.1046/j.14690691.2001.00210.x

${ }^{25}$ R. Teanpaisan, C. W. Douglas, T. F. Walsh, Characterisation of black-pigmented anaerobes isolated from diseased and healthy periodontal sites, J Periodontal Res, 30 (1995), 245-51, doi:10.1111/ j.1600-0765.1995.tb02129.x

${ }^{26}$ R. L. Boyd, Longitudinal evaluation of a system for self-monitoring plaque control effectiveness in orthodontic patients, J Clin Periodontol, 10 1983/07/01 ed (1983), 380-8, doi:10.1111/j.1600051x.1983.tb01287.x

${ }^{27}$ P. Zhu, H. Lin, Y. Han, Y. Lin, Y. Xu, Z. Zhang, A computational fluid dynamic analysis of peri-bracket salivary flow influencing the microbial and periodontal parameters, PLoS One, 8 (2013), e62242, doi:10.1371/journal.pone.0062242

${ }^{28}$ B. Rowshani, M. F. Timmerman, U. Van der Velden, Plaque development in relation to the periodontal condition and bacterial load of the saliva, J Clin Periodontol, 31 (2004), 214-8, doi:10.1111/j.03036979.2004.00468.x

${ }^{29}$ P. Ramberg, P. Axelsson, J. Lindhe, Plaque formation at healthy and inflamed gingival sites in young individuals, J Clin Periodontol, 22 (1995), 85-8, doi:10.1111/j.1600-051x.1995.tb01775.x

${ }^{30}$ I. S. Marques, A. M. Araujo, J. A. Gurgel, D. Normando, Debris, roughness and friction of stainless steel archwires following clinical use, Angle Orthod, 80 (2010), 521-7, doi:10.2319/081109-457.1

${ }^{31}$ R. C. Araujo, L. M. Bichara, A. M. Araujo, D. Normando, Debris and friction of self-ligating and conventional orthodontic brackets after clinical use, Angle Orthod, 85 (2015), 673-7, doi:10.2319/012914-80.1

${ }^{32}$ W. E. Moore, L. V. Holdeman, R. M. Smibert, D. E. Hash, J. A. Burmeister, R. R. Ranney, Bacteriology of severe periodontitis in young adult humans, Infect Immun, 38 (1982), 1137-48

${ }^{33}$ Y. Yoshida, N. Suzuki, Y. Nakano, K. Shibuya, Y. Ogawa, T. Koga, Distribution of Actinobacillus actinomycetemcomitans serotypes and Porphyromonas gingivalis in Japanese adults, Oral Microbiol Immunol, 18 (2003), 135-9, doi:10.1034/j.1399-302x.2003.00034.x
${ }^{34}$ M. P. Riggio, T. W. Macfarlane, D. Mackenzie, A. Lennon, A. J. Smith, D. Kinane, Comparison of polymerase chain reaction and culture methods for detection of Actinobacillus actinomycetemcomitans and Porphyromonas gingivalis in subgingival plaque samples, J Periodontal Res, 31 (1996), 496-501, doi:10.1111/j.16000765.1996.tb01415.x

${ }^{35}$ A. Sotošek, P. Videmšek, K. Seme, R. Gašperšič, Bakteriološka analiza subgingivalnih zobnih oblog slovenskih bolnikov s kroničnim parodontitisom, Zobozdrav vestn, 69 (2014), 12-20

${ }^{36}$ J. Lindhe, N. P. Lang, T. Karring, Clinical Periodontology and Implant Dentistry, Oxford, Blackwell Munnksgard, 6th ed 2011

${ }^{37}$ B. K. Wong, N. R. McGregor, H. L. Butt, R. Knight, L. Y. Liu, I. B. Darby, Association of clinical parameters with periodontal bacterial haemolytic activity, J Clin Periodontol, 43 (2016), 503-11, doi:10.1111/jcpe. 12554

${ }^{38}$ A. J. Ireland, V. Soro, S. V. Sprague, N. W. Harradine, C. Day, S. Al-Anezi, H. F. Jenkinson, M. Sherriff, D. Dymock, J. R. Sandy, The effects of different orthodontic appliances upon microbial communities, Orthod Craniofac Res, 17 (2014), 115-23, doi:10.1111/ ocr. 12037

${ }^{39}$ M. J. Thornberg, C. S. Riolo, B. Bayirli, M. L. Riolo, E. A. Van Tubergen, R. Kulbersh, Periodontal pathogen levels in adolescents before, during, and after fixed orthodontic appliance therapy, Am J Orthod Dentofacial Orthop, 135 (2009), 95-8, doi:10.1016/ j.ajodo.2007.02.057

${ }^{40}$ G. Perinetti, M. Paolantonio, E. Serra, D. D'Archivio, S. D'Ercole, F. Festa, G. Spoto, Longitudinal monitoring of subgingival colonization by Actinobacillus actinomycetemcomitans, and crevicular alkaline phosphatase and aspartate aminotransferase activities around orthodontically treated teeth, J Clin Periodontol, 31 (2004), 60-7, doi:10.1111/j.0303-6979.2004.00450.x

${ }^{41}$ J. F. Moulder, W. F. Stickle, P. E. Sobol, K. D. Bomben, Handbook of X-Ray Photoelectron Spectroscopy, Physical Electronics Inc., Eden Prairie, Minnesota, USA, (1995)

${ }^{42}$ U. Mezeg, Evaluation of the surface characteristics of orthodontic brackets, archwires and their intraoral degradation processes, Doctoral thesis, Medical faculty, University, 2018, Ljubljana 